\title{
A DIFFERENT LOOK AT BIOGEOCHEMISTRY
}

\author{
ROBERT A. BERNER \\ Department of Geology and Geophysics, Yale University, P. O. Box 208109, \\ New Haven, Connecticut 06520-8109, USA; robert.berner@yale.edu
}

Most of this volume deals with microbes and, especially with their interactions with surfaces. Another aspect of biogeochemistry deals with plants and animals. Microbes were the dominant forms of life during the Precambrian, but over the past 550 million years (the Phanerozoic eon) the evolution of higher plants and animals and their interaction with the environment also have been important. It is my purpose here to give a few examples of these other aspects of biogeochemistry.

\section{PLANTS AND THE ATMOSPHERE}

It is my personal view that the rise of large vascular land plants during the Devonian was nearly as important to the evolution of life and the atmosphere as the rise of microbial photosynthesis during the Archaean. The new plants, especially trees, accelerated the removal of $\mathrm{CO}_{2}$ from the atmosphere and the addition of $\mathrm{O}_{2}$ to it, resulting in changes in the levels of both gases (Berner, 2004; Beerling and Berner, 2005). Changes in $\mathrm{CO}_{2}$ resulted in climate change due to the atmospheric greenhouse effect and changes in the level of $\mathrm{O}_{2}$ resulted in changes in respiratory function that likely affected the evolution of animals (Ward, 2006). Also, without higher plants most herbivores would not have arisen.

Trees and other higher plants affect $\mathrm{CO}_{2}$ and $\mathrm{O}_{2}$ by basically two processes. First, there is removal of $\mathrm{CO}_{2}$ by enhanced mineral weathering. This comes about by the overall global reaction, first deduced by Ebelmen (1845):

$$
\mathrm{CO}_{2}+(\mathrm{Ca}, \mathrm{Mg}) \mathrm{SiO}_{3} \rightarrow(\mathrm{Ca}, \mathrm{Mg}) \mathrm{CO}_{3}+\mathrm{SiO}_{2}
$$

whereby $\mathrm{CO}_{2}$ reacts with $\mathrm{Ca}$ and $\mathrm{Mg}$ silicates to form $\mathrm{Ca}^{++}, \mathrm{Mg}^{++}$and $\mathrm{HCO}_{3}^{-}$in solution, the dissolved elements are carried to the ocean by rivers, and then are precipitated in the oceans to form $\mathrm{Ca}$ and $\mathrm{Mg}$ carbonates. Acceleration of weathering by higher plants is due to the vast interfacial soil/root surface area provided by plants and associated symbiotic microflora. Trees and other higher plants grow and take up mineral-derived nutrients, such as $\mathrm{Ca}, \mathrm{Mg}$ and $\mathrm{K}$, much faster than do the microbes or bryophytes that are believed to have inhabited the land surface before trees (Berner and Berner, 2003). Also, photosynthesis by trees, grasses and other plants ultimately provides most all of the energy for the activities of soil microbiota.

The other major process affecting atmospheric composition is the synthesis by trees and other woody plants of lignin, a relatively non-biodegradable substance. Burial of lignin-derived organic matter in sediments accompanying the rise of higher plants must have led to greater global organic matter burial and, therefore, greater $\mathrm{CO}_{2}$ removal and $\mathrm{O}_{2}$ liberation to the atmosphere. The effects of organic matter burial can be seen from the overall reaction (also deduced by Ebelmen, 1845):

$$
\mathrm{CO}_{2}+\mathrm{H}_{2} \mathrm{O} \rightarrow \mathrm{CH}_{2} \mathrm{O}+\mathrm{O}_{2}
$$

This is not just the reaction for photosynthsis; photosynthesis by itself does not affect $\mathrm{O}_{2}$ and $\mathrm{CO}_{2}$ over the long term because it is almost totally balanced globally by respiration (reaction (2) backwards). Only burial of organic matter in sediments, representing a small excess of photosynthesis over respiration, is important over millions of years for control of $\mathrm{CO}_{2}$ and $\mathrm{O}_{2}$. 
MARINE ORGANISMS AND PAST ENVIRONMENTS

Another aspect of biogeochemistry is the study of the evolution and chemical and isotopic composition of fossils of marine organisms as indicators of the state of ancient oceans. (There has been so much work in this field that any referencing here would be superfluous.) Microbial biomarkers are very useful for this purpose as pointed out in this volume by the review by Nealson and Popa. But there are also such classical things as the use of oxygen isotopes, carbon isotopes and the chemical composition of calcareous fossils to deduce ancient seawater temperature and chemical composition and for studying the global carbon cycle.

The rise of calcareous phytoplankton and zooplankton during the Mesozoic provide an example of a marine biogeochemical process that has had an effect, albeit indirect, on the composition of the atmosphere. The shift of carbonate deposition from shallow waters and continental shelves to the deep sea occurred as a result of the rise and spread of forams, coccoliths and other calcareous plankton (Wilkinson and Walker, 1989). This had two effects. First, deposition onto the deep sea floor stabilized the concentration of dissolved $\mathrm{CO}_{3}^{-2}$ and, by air-sea gas exchange, the level of atmospheric $\mathrm{CO}_{2}$ (Ridgwell and others, 2003). This stabilization was limited prior to the rise of calcareous plankton because $\mathrm{CO}_{3}^{-2}$ could build up in the sea, and $\mathrm{CO}_{2}$ diminish, whenever sea level dropped and there was less available continental shelf space for carbonate deposition. Another effect is that deposition onto the deep sea floor caused subducting seafloor eventually to become higher in $\mathrm{CaCO}_{3}$, and after burial to sufficient depth, thermal decomposition of more carbonate must have produced more $\mathrm{CO}_{2}$ that was eventually degassed to the atmosphere.

\section{SUMMARY}

In brief the plea here is for more studies of macro-organisms, their physiology, their evolution and their relation to geochemical cycles and evolution of the environment. The present volume shows that there is much interest in geomicrobiology. More attention needs to be given in the future to plants and animals.

ACKNOWLEDGMENTS

The writer has benefited from discussions with David Beerling and Peter Ward.

\section{REFERENCES}

Beerling, D. J., and Berner, R. A., 2005, Feedbacks and the co-evolution of plants and atmospheric $\mathrm{CO}_{2}$ : Proceedings of the National Academy of Sciences, v. 102, 1302-1305.

Berner, E. K., Berner R. A., and, Moulton, K. L, 2003, Plants and mineral weathering: present and past: Treatise on Geochemistry, v. 5, p. 169-188.

Berner, R. A., 2004, The Phanerozoic Carbon Cycle: $\mathrm{CO}_{2}$ and $\mathrm{O}_{2}$ : Oxford, Oxford University Press, 150 p.

Ebelmen, J. J., 1845, Sur les produits de la décomposition des espèces minérales de la famille des silicates: Annales des Mines, v. 7, p. 3-66.

Ridgwell, A. J., Kennedy, M. J., and Caldeira, K., 2003, Carbonate deposition, climate stability, and Neoproterozoic ice ages: Science, v. 302, p. 859-862.

Ward, P. D., 2006, A New History of Life; Respiration and Animal Design: Washington, D. C., National Academy Press.

Wilkinson, B. H., and Walker, J. C. G., 1989, Phanerozoic cycling of sedimentary carbonate: American Journal of Science, v. 289, p. 525-548. 